\title{
PENGUATAN KEMAMPUAN BERPIKIR LOGIS PADA GURU-GURU PPKn DI MGMP MAGETAN
}

\author{
Oleh: \\ Oksiana Jatiningsih1, Siti Maizul Habibah ${ }^{2}$, Agus Satmoko Adi $^{3}$, Totok Suyanto ${ }^{4}$, Warsono \\ Jurusan PMP-KN, FISH, Unesa \\ 10ksianajatiningsih@unesa.ac.id,
}

\begin{abstract}
Abstrak
Berpikir logis merupakan cara berpikir yang mengantarkan seseorang untuk dapat membuat pernyataan dan keputusan secara tepat berdasarkan logika dan rasional. Kecakapan ini sangat diperlukan dalam berkomunikasi dan menulis karya ilmiah. Berdasarkan observasi awal yang dilakukan, hal ini menjadi salah satu kendala yang dialami guru PPKn di Magetan dalam menulis ilmiah. Oleh karena itu, melalui kegiatan latihan berpikir logis ini dilakukan upaya penguatan kemampuan berpikir logis pada guru-guru yang tergabung di MGMP PPKn Magetan. Sesuai dengan itu, tujuan kegiatan pengabdian ini adalah untuk meningkatkan pemahaman guru tentang kaidah berpikir logis dan meningkatkan kemampuan guru berpikir logis sebagai dasar dalam penulisan karya ilmiah. Kegiatan yang diikuti oleh 25 guru PPKn ini dilaksanakan di SMA Negeri 1 Magetan, dengan tahapan kegiatan: mengungkapkan kesesatan dalam berpikir melalui latihan, diskusi tentang kesesatan berpikir logis, penguatan kaidah berpikir logis, dan latihan menulis berbasis logika. Kegiatan pengabdian ini telah berhasil dalam meningkatkan dasar-dasar kemampuan guru dalam berpikir logis. Guru lebih memahami bahwa dalam menulis diperlukan logika berpikir yang cermat, kemampuannya menyusun tulisan sederhana yang logis juga meningkat, namun untuk dapat menulis ilmiah yang dapat dipublikasikan, diperlukan latihan dan pendampingan yang lebih lanjut.
\end{abstract}

Kata Kunci: berpikir logis, menulis ilmiah.

\section{Abstract}

Logical thinking is a way of thinking that leads a person to be able to make correct statements and decisions based on logic and rationale. This skill is indispensable in communicating and writing scientific papers. Based on preliminary observations made, this is one of the obstacles experienced by PPKn teachers in Magetan in scientific writing. Therefore, through this logical thinking exercise, efforts were made to strengthen the logical thinking skills of teachers who are members of the MGMP PPKn Magetan. In accordance with that, the purpose of this service activity is to increase teacher understanding of the rules of logical thinking and increase the ability of teachers to think logically in the context of scientific writing. The activity which was attended by 25 PPKn teachers was carried out at SMA Negeri 1 Magetan, with stages: revealing fallacy in thinking through exercises, discussions about logical thinking fallacies, strengthening logical thinking rules, and logic-based writing exercises. This service activity has been successful in improving the basics of the teacher's ability to think logically. The teacher better understands that in writing, careful thinking logic is needed, the ability to compose simple logical writing also increases, but to be able to write scientifically that can be published, further training and assistance is needed.

Keywords: logical thinking, academic writing.

\section{PENDAHULUAN}

Menulis merupakan aktivitas berbahasa untuk menuangkan pikiran dan perasaan secara tertulis. Pengungkapan pikiran dan perasaan ini dilakukan melalui proses berpikir Oleh karena itu, kualitas berpikir seorang penulis akan menentukan pula kualitas tulisan yang dihasilkannya.

Karya tulis penting dalam pengembangan profesi. Karena itu, menulis karya ilmiah merupakan syarat mutlak bagi guru dalam rangka untuk pengembangan karir atau jabatan fungsionalnya (Depdiknas, 2001). Karena itu, guru dituntut untuk memiliki kompetensi meneliti dan menulis karya ilmiah baik berupa artikel ilmiah, modul, atau buku.

Publikasi karya ilmiah dan/atau karya inovatif merupakan bagian dari upaya pengembangan keprofesionalan guru yang berkelanjutan bagi guru yang hendak naik pangkat dari mulai golongan ruang $\mathrm{III} / \mathrm{b}$ ke III/c dan di atasnya. Sebenarnya kewajiban ini sudah diatur dalam Peraturan Menteri Negara Pendayagunaan Aparatur Negara dan 
Reformasi Birokrasi Nomor 16 Tahun 2009 tentang Jabatan Fungsional Guru dan Angka Kreditnya, namun pelaksanaannya ditunda hingga tahun 2013 sebagaimana diatur dalam Permendiknas Nomor 35 Tahun 2010. Menurut pasal 11 Peraturan Menteri Negara Pendayagunaan Aparatur Negara dan Reformasi Birokrasi Nomor 16 Tahun 2009, dalam rangka pengembangan keprofesionalan diri guru dituntut untuk melakukan: (1) publikasi ilmiah atas hasil penelitian atau gagasan inovatif pada bidang pendidikan formal; dan (2) publikasi buku teks pelajaran, buku pengayaan, dan pedoman. Hanya guru yang mampu mengembangkan profesionalismenya melalui publikasi karya ilmiah dan/atau karya inovatifnya yang dapat mengajukan kenaikan pangkat.

Guru memiliki kewajiban melakukan publikasi. Sayang sekali, banyak guru terkendala kenaikan kepangkatan karena belum memiliki karya ilmiah. Guru-guru di Gresik masih menghadapi masalah dengan publikasi ilmiah dan karena itu masih banyak memerlukan pendampingan (https://radarsurabaya.jawapos.com/read/201 8/06/23/82581/kemampuan-guru-menulismasih-minim). Problematika yang sama juga terjadi di berbagai daerah yang lain. Sumardjoko (2017) mengungkapkan bahwa guru-guru bersertifikasi pendidik di SMA/MA/SMK Muhammadiyah di Sukoharjo belum sepenuhnya memahami konsep karya ilmiah dan memiliki kemampuan menulis karya ilmiah. Noorjanah (2017) dalam penelitiannya juga mengungkapkan bahwa secara umum pengembangan professionalisme guru SMA Negeri 1 Kauman Tulungagung melalui menulis karya ilmiah khususnya penulisan Penelitian Tindakan Kelas, masih kurang dan perlu mendapatkan perhatian dan bimbingan secara serius.

Di Magetan guru-guru pun menghadapi persoalan terkait kewajiban melakukan publikasi ilmiah. Bahkan karena tuntutan itu, beredar isu adanya pekerjaan calo karya ilmiah (Penjahit Karya Tulis) yang dapat dimanfaatkan guru ketika mengalami kendala dalam mengajukan kenaikan pangkat (https://lensamagetan.com/2018/11/05/calopkt-berkeliaran-ini-kata-ketua-pgri-magetan/)

Berdasarkan studi pendahuluan yang dilakukan, dapat dikemukakan bahwa peningkatan kemampuan membuat karya ilmiah, khususnya yang berdasarkan hasil pemikiran, mendesak untuk dicarikan solusi. Hasil konsultasi dengan ketua MGMP PPKn di tingkat SMA/SMK Kabupaten Magetan menunjukkan bahwa salah satu persoalan yang dihadapi oleh guru-guru PPKn di Kabupaten Magetan adalah kemampuan guru dalam menulis ilmiah. Lebih lanjut, salah satu persoalan mendasar yang menjadi kendala terkait rendahnya kemampuan menulis tersebut adalah kemampuan guru dalam mengembangkan alur berpikir yang logis dalam menulis ilmiah.

Setiap tulisan ilmiah memuat pernyataan yang memiliki kebenaran sebagai buah dari suatu proses berpikir. Norris dan Ennis (1991; 1989) mengemukakan bahwa berpikir logis adalah pemikiran yang masuk akal dan reflektif yang berfokus pada memutuskan apa yang mesti dipercaya atau dilakukan (Ennis, 1996). Definisi lain dikemukakan oleh Paul, Fisher dan Nosich (1993) bahwa berpikir logis sebagai mode berpikir mengenai hal, substansi, atau masalah penting untuk meningkatkan kualitas pemikiran seseorang dengan menangani secara terampil strukturstruktur yang melekat dalam pemikiran dan menerapkan standar-standar intelektual (kejelasan, relevansi, masuk akal, kebenaran, keadilan, dan lain-lain). Standar intelektual ini menjadi moralitas yang harus dipegang dalam berpikir logis.

Berpikir logis memberikan kekuatan untuk melawan dunia yang begitu banyak informasi dan kepalsuan yang meyakinkan, sehingga setiap orang menjadi dapat mendengar dan melihat dengan lebih baik dan makin kuat (Ebstein, 2006). Berpikir logis memungkinkan seseorang bergerak dari satu posisi ke posisi yang baru (de Bono, 1993). Maksudnya, dari satu kalimat ke kalimat yang lain, dari argumen yang satu ke argumen yang lain, dari satu ide ke ide yang lain. Karena itu, tujuan berpikir logis adalah membangun pernyataan (klaim), sehingga dapat dibedakan argumentasi yang baik dan buruk (Hurley dan Watson, 2018) menuju pengambilan suatu kesimpulan.

Dalam keseharian, argumentasi inilah yang menjadi alasan mengapa seseorang melakukan atau tidak melakukan sesuatu. Karena itu, berpikir logis menunjukkan keterampilan seseorang untuk memilih melakukan atau tidak melakukan sesuatu (Fisher, 2009). Dalam kaitannya dengan kegiatan menulis ilmiah, berpikir logis ini menjadi kerangka bagi seorang penulis dalam menentukan kata dan kalimat yang akan ditulis untuk dirangkai menjadi paragraf dalam suatu tulisan.

Memperoleh kebenaran dan keputusan adalah produk dari proses berpikir logis. 
Berpikir logis merupakan berpikir menurut pula aturan tertentu atau inferensi logis tau prinsip-prinsip logika untuk memperoleh suatu kesimpulan (Suryasumantri, 1996). Karena ketaatannya pada aturan berpikir inilah, maka berpikir logis dapat menghindarkan seseorang dari kesesatan berpikir, yang berdampak pada kesesatan dalam mengambil keputusan atau kesimpulan. Yang dimaksud dengan sesat berpikir adalah proses penalaran atau argumentasi yang sebenarnya tidak logis, salah arah, dan menyesatkan yang bisa saja terjadi karena pemaksaan prinsip-prinsip logika tanpa memperhatikan relevansinya (Sumaryono, 1999). Hal ini tentu tidak boleh terjadi dalam menulis ilmiah.

Keputusan melakukan atau tidak melakukan sesuatu dalam aktivitas menulis terekspresikan dalam keputusan penulis dalam mengungkapkan dan menyusun pernyataan-pernyataan dalam tulisannya. Hubungan inferensial antara pernyataanpernyataan tersebut merupakan klaim yang menyiratkan adanya bukti yang mendukung sesuatu, yang disebut sebagai argumen (Hurley dan Watson, 2018).

Berpikir logis merupakan syarat dalam berpikir kritis. Moore \& Parker (2009) mengemukakan bahwa karakteristik berpikir kritis adalah menentukan informasi yang tepat, membedakan klaim yang rasional dan emosional, memisahkan antara fakta dan pendapat, menentukan bukti apakah terbatas atau bisa diterima, menunjukkan tipuan dan kekurangan dalam argumentasi orang lain, menunjukkan analisis data atau informasi, menyadari kesalahan logika, menggambarkan hubungan antara sumbersumber data yang terpisah, memperhatikan informasi yang bertentangan dan tidak memadai. Lebih lanjut dijelaskan bahw berpikir logis juga berkaitan dengan membangun argumen yang meyakinkan yang berbasis pada data, memilih data penunjang yang paling kuat, menghindari kesimpulan yang berlebihan, mengidentifikasi celah-celah dalam bukti dan menyarankan pengumpulan informasi tambahan, menyadari tidak jelas atau banyaknya kemungkinan jawaban suatu masalah, mengusulkan opsi lain dalam pengambilan keputusan, mempertimbangkan semua pemangku kepentingan atau, menyatakan argumen dan konteks untuk apa argumen itu, menggunakan bukti secara betul dan tepat untuk menyanggah argumen, menyusun argumen secara logis dan kohesif, menunjukkan bukti untuk mendukung argumen yang meyakinkan. Berpikir logis menawarkan pengambilan keputusan atau kesimpulan berdasarkan data dan pemikiran yang matang yang mempertimbangkan secara komprehensif berbagai hal. Dalam konteks tulisan ilmiah, berpikir logis akan menawarkan terciptanya keruntutan dan keutuhan tulisan dan penyampaian sesuatu secara jelas dalam jalinan berpikir yang cermat dan bisa diterima.

Karena itu, kegiatan pengabdian ini dimaksudkan untuk meningkatkan kemampuan dasar guru dalam berpikir logis dalam rangka penulisan ilmiah. Secara operasional tujuan kegiatan pengabdian ini adalah untuk meningkatkan pemahaman guru terhadap kaidah berpikir logis dan meningkatkan kemampuan guru berpikir logis sebagai dasar dalam penulisan karya ilmiah setelah mengikuti kegiatan pengabdian ini.

\section{METODE}

Sasaran kegiatan ini adalah 25 guru PPKn di MGMP Kabupaten Magetan. Kegiatan yang dilakukan dalam kegiatan pengabdian kepada masyarakat ini menggunakan beberapa metode yaitu:

1. Diskusi Kelompok Terpimpin (Focus Group Discussion). Kegiatan ini dimaksudkan untuk merumuskan secara rinci problema yang dihadapi peserta dalam menulis ilmiah.

2. Pelatihan digunakan untuk penyuluhan tentang substansi kegiatan yang disertai dengan demonstrasi atau percontohan untuk realisasinya, b) pelatihan dalam mengembangkan kemampuan peserta dalam mengembangkan kalimat-kalimat dan tulisan sederhana berdasarkan logika berpikir yang benar.

3. Workshop digunakan untuk mengembangkan keterampilan guru dalam berpikir logis dan menunagkan hasil pemikirannya dalam bentuk tulisan sederhana. Kegiatan ini dilanjutkan dengan presentasi draft tulisan yang sudah dihasilkan peserta untuk didiskusikan lebih lanjut.

Bentuk kegiatan yang dilakukan dalam waktu empat bulan ini dalam bentuk kegiatan pengabdian kepada masyarakat ini adalah sebagai berikut. 
Tabel 1 Kerangka Pemecahan Masalah

\begin{tabular}{ll}
\hline No & Masalah \\
\hline 1. & $\begin{array}{c}\text { Pengetahuan guru tentang } \\
\text { berpikir dan karakteristik artikel }\end{array}$ \\
\hline 2. & Pengetahuan tentang logika pen \\
\hline 3. & Keterampilan guru dalam m \\
tulisan dalam alur logika yang ben
\end{tabular}

Adapun kriteria keberhasilan kegiatan pengabdian kepada masyarakat ini dinilai berhasil dengan baik apabila:

(1) minimum $75 \%$ guru memahami $75 \%$ materi dengan baik;

(2) minimum $75 \%$ guru dapat menyusun perencanaan berbasis berpikir logis.

\section{HASIL DAN PEMBAHASAN}

\section{Persiapan Kegiatan}

Pada tingkat internal tim pelaksana kegiatan PKM, koordinasi dilakukan pula untuk penyusunan strategi kegiatan, bahan dan kelengakapan pelatihan, instrumen yang diperlukan, dan pengurusan surat izin atau surat tugas pelaksanaan PKM. Berdasarkan koordinasi yang dilakukan, disepakati bahwa pada hari pertama anggota tim yang bertugas adalah terutama Oksiana Jatiningsih dan Totok Suyanto.

Sebelum kegiatan dilaksanakan tim PKM Berpikir Logis melakukan koordinasi dan penyiapan PKM. Untuk itu pada tanggal 12 Maret 2019 di kantor jurusan PMP-KN dilakukan koordinasi internal tim PKM. Dalam

rapat koordinasi ini dilakukan pembagian tugas pengembangan materi dan presentasi saat kegiatan PKM dilaksanakan. Selang dua minggu kemudian, melalui telepon dilaksanakan kegiatan koordinasi eksternal dengan mitra terkait dengan waktu pelaksanaan kegiata PKM. Dengan memperhatikan kesibukan masing-masing anggota tim PKM dan kegiatan di seolah maka, pertemuan pertama kegiatan PKM diselenggarakan pada tanggal 6 September 2019.

Tahap pertama kegiatan adalah koordinasi. Koordinasi pertama dilakukan tim PKM dengan ketua MGMP PPKn Kabupaten Magetan. Koordinasi dilakukan melalui Whats App. Berdasarkan kesepakatan, maka ditentukan tanggal 6 dan 7 September 2019 sebagai pertemuan awal kegiatan. Lokasi kegiatan adalah SMAN 1 Magetan.

Koordinasi lain yang juga dilakukan adalah terkait dengan akomodasi. Berdasarkan kesepakatan antara tim PKM dengan guru yang ditunjuk yayasan untuk berkomunikasi tentang biaya penyediaan konsumsi dilakukan oleh tim PKM selama kegiatan dilaksanakan. Kesepakatan yang lain terkait dengan waktu atau jadwal pelaksanaan kegiatan pengabdian ini. Kegiatan pengabdian disepakati dilaksanakan dalam dua kali pertemuan tatap muka dan sekali kegiatan terstruktur yang dilaksanakan mandiri secara individual. Durasi waktu untuk sekali pertemuan adalah delapan jam mulai pukul 08.00-16.00.

\section{Pelaksanaan Kegiatan}

Secara operasional kegiatan PKM ini dilaksanakan dalam dua kali pertemuan, yang di antara keduanya terdapat jeda dua minggu. Jeda waktu ini dipergunakan untuk pengembangan dan evaluasi rencana pembelajaran oleh guru secara mandiri. Adapun secara keseluruhan kegiatan dan materi tersebut direncanakan sebagai berikut. 
Tabel 3 Pelaksanaan Kegiatan PKM Berpikir Logis

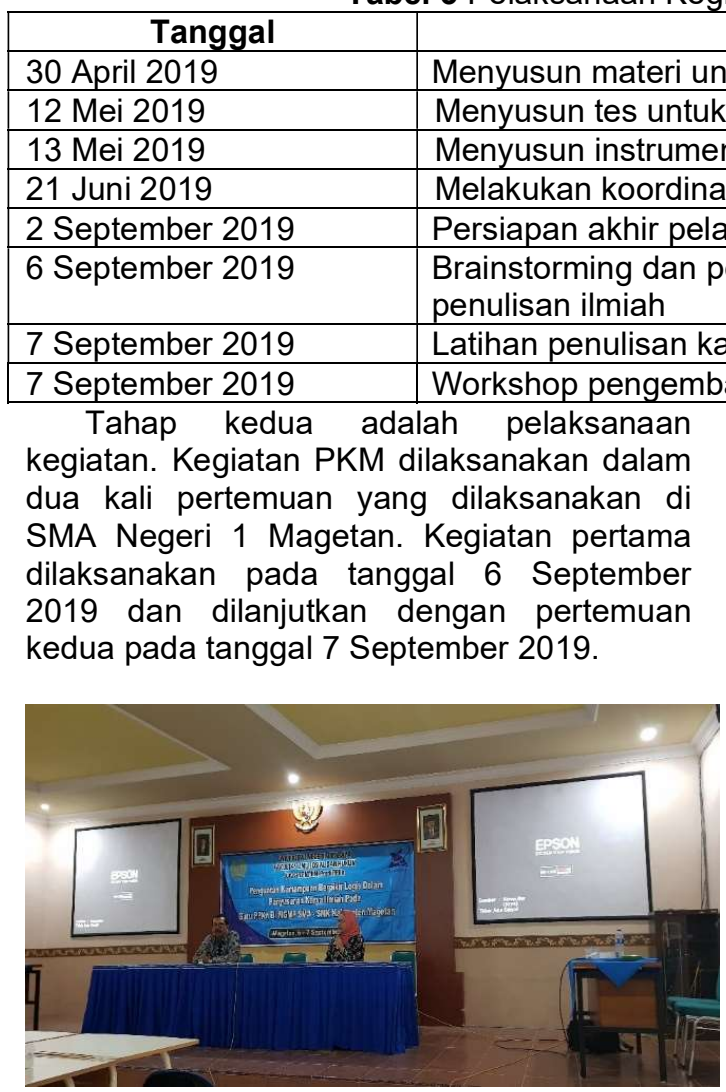

Gambar 1 Pembukaan Kegiatan PKM Kegiatan workshop ini diawali dengan kegiatan brainstorming tentang Penulisan dan logika ilmiah. Beberapa catatan penting dalam brainstorming ini adalah:

1) Berpikir logis adalah berpikir yang masuk akal.

2) Berpikir logis penting dalam membangun kalimat ilmiah.

3) Berpikir logis dibangun oleh pilihan kata dalam menulis kalimat.

4) Berpikir logis dapat berlangsung secara deduktif atau induktif.

5) Berpikir logis adalah syarat untuk menulis ilmiah.

Hasil brainstorming ini menunjukkan bahwa kegiatan pengembangan kemampuan berpikir logis dan menulis logis ini memang diperlukan. Kesalahan konsep dalam berpikir logis menyebabkan mereka mengalami kekeliruan dalam mengungkapkan fenomena atau realita atau penjelasan yang hendak ditulis.

\section{Pengetahuan Guru tentang Berpikir Logis}

Pengetahuan "Berpikir Logis" penting dimiliki oleh guru, karena pada dasarnya guru

\section{Kegiatan}

kegiatan pelatihan

engukur tes logika ilmiah penulisan

pelaksanaan kegiatan

anaan PKM

enyampaian materi tentang Logika dalam kalimat yang logis

yang memiliki kemampuan berpikir logis yang akan dapat menjadi model dalam berpikir logis pula bagi peserta didiknya. Kemampuan berpikir logis penting dimiliki guru dalam mengembangkan suatu tulisan. Berpikir logis dalam tingkatan yang sederhana berupa pemanfaatan referensi sebagai dasar untuk menarik kesimpulan. Referensi dasar tindakan ini menjadikan seseorang tidak mudah terombang-ambing oleh derasnya pengaruh informasi yang diterimanya dalam kehidupan nyata. Selain itu, referensi dan dasar keyakinan tindakan yang dimiliki seseorang juga menyediakan referensi yang bermakna bagi seseorang sehingga ia makin memiliki keyakinan kebenaran suatu pengetahuan dan/atau nilai, tidak mudah terombang-ambing oleh dunia, namun tetap memiliki keterbukaan terhadap pemikiran orang lain dan kebersediaan untuk berubah karena pemikiran lain yang lebih baik. Kemampuan ini penting dimiliki oleh setiap orang, apalagi dalam tulisan, penulis tidak lagi menyertai tulisannya ketika dibaca oleh orang lain. Inilah moment ketika penulis telah mati.

Hasil pre tes dan post test tentang pengetahuan berpikir logis guru dapat dicermati pada tabel 4 berikut ini.

Tabel 4 Hasil Pre Test tentang Pengetahuan Berpikir Logis

\begin{tabular}{|c|c|r|c|c|c|}
\hline $\begin{array}{c}\text { Interval } \\
\text { Nilai }\end{array}$ & Katagori & \multicolumn{2}{|c|}{ Pre } & \multicolumn{2}{c|}{ Post } \\
\hline $1-5$ & Kurang & 4 & $16 \%$ & 0 & $0 \%$ \\
\hline $6-10$ & Cukup & 15 & $60 \%$ & 1 & $4 \%$ \\
\hline $11-15$ & Baik & 6 & $24 \%$ & 24 & $96 \%$ \\
\hline
\end{tabular}

Sumber: data primer

Berdasarkan data pada tabel 4 tentang hasil tes pengetahuan berpikir logis yang dilakukan pada awal kegiatan, dapat dikemukakan bahwa sebagian besar guru $(60 \%)$ yang mengikuti kegiatan ini memiliki pengetahuan berpikir logis dalam katagori 
"cukup baik." Masih ada di antara mereka (16\%) yang memiliki katagori "kurang baik." Artinya kemampuan guru tentang persoalan ini perlu ditingkatkan. Oleh karena itu, kegiatan workshop tentang berpikir logis dan pengembangan kemampuan berpikir logis dalam pembelajaran perlu dilaksanakan. Perbandingan jumlah pada masing-masing katagori yang dibuat untuk menggambarkan pengetahuan guru tentang kemampuan berpikir logis ini dapat dilihat pada grafik 5.1 berikut ini.

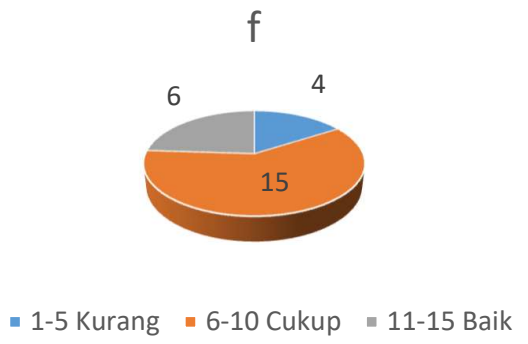

Grafik 5.1 Hasil Pretest tentang Pengetahuan Berpikir Logis (Sumber: data primer)

Pengetahuan guru yang cukup dan kurang baik ini sangat mungkin berkaitan pula dengan kemampuannya dalam mengembangkan kemampuan berpikir logis pada peserta didiknya. Berdasarkan data, dapat dikemukakan Setelah kegiatan pelatihan $96 \%$ guru memiliki logika berpikir yang baik, dan tak satu pun yang berada pada katagori kurang. Perbandingan skor sebelum dan sesudah guru setelah mengikuti kegiatan PKM ini dapat disimak pada tabel 5.3.

Secara visual perbandingan pengetahuan guru dalam berpikir logis antara sesudah dan sebelum pelaksanaan kegiatan PKM dapat disimak pada grafik 5.2 berikut ini.

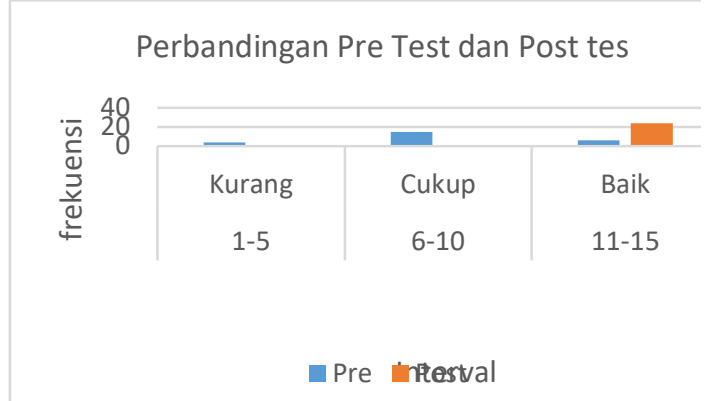

Grafik 5.2 Perbandingan Pre Test dan Post Test

Berdasarkan grafik 5.2, dengan sangat jelas dapat dibandingkan hasil pre test dan post tes peserta. Logika berpikir mereka

berkembang lebih baik sehingga setelah kehiatan PKM, tidak ada peserta yang kemampuan logikanya dikatagorikan kurang.

\section{Gambaran Kemampuan Guru dalam Menulis Logis}

Kemampuan guru dalam menulis memang masih perlu dilakukan. Dalam kegiatan untuk merangsang guru menulis, setelah proses latihan mengungkap logika berpikir. Peserta diminta untuk menulis tentang pengalaman pribadinya ketika berhadapan dengan persoalan peserta didik yang kurang menyenangkan. Secara umum mereka menulis tetapi yang ditampilkan beragam. Peserta diminta menulis paragraph tentang topik tersebut, tetapi beberapa guru membuat daftar perasaannya.

1. Buat satu paragraf tulisan tentang

perasaan bapak ibu ketika menghadapi

murid yang berperilaku tidak terpuji.

2. Buat satu paragraf tulisan tentang

pengalaman bapak ibu menghadapi murid

yang berperilaku tidak terpuji.

3. Buat satu paragraf tulisan tentang

strategi bapak ibu ketika menghadapi

murid yang berperilaku tidak terpuji

Gambar 5.1 Materi tentang Pengetahuan Berpikir Logis (Sumber: data primer)

Salah satu peserta bukan menulis kalimat-kalimat, tetapi malah membuat daftar perasaan. Mungkin karena peserta ini kurang memahami perintah yang diberikan.

\begin{tabular}{|c|c|}
\hline $\begin{array}{ll} & \text { Perasaa } \\
\text { 1. } & \text { Sedih sekali } \\
\text { 2. } & \text { Rasa duka } \\
\text { 3. } & \text { Kecewa } \\
\text { 4. } & \text { Berat di hati } \\
\text { 5. } & \text {.... }\end{array}$ & n saya: \\
\hline \multicolumn{2}{|c|}{$\begin{array}{l}\text { Gambar 5.2 Materi tentang Pengetahuan } \\
\text { Berpikir Logis (Sumber: data primer) }\end{array}$} \\
\hline $\begin{array}{l}\text { Pada tahap } \\
\text { diminta menulis } \\
\text { kewarganegaraan. } \\
\text { menulis topik-topik } \\
\text { yaitu: }\end{array}$ & $\begin{array}{l}\text { selanjutnya, peserta } \\
\text { dengan } \\
\text { topik } \\
\text { anerta diminta untuk } \\
\text { ang telah ditentukan, }\end{array}$ \\
\hline
\end{tabular}




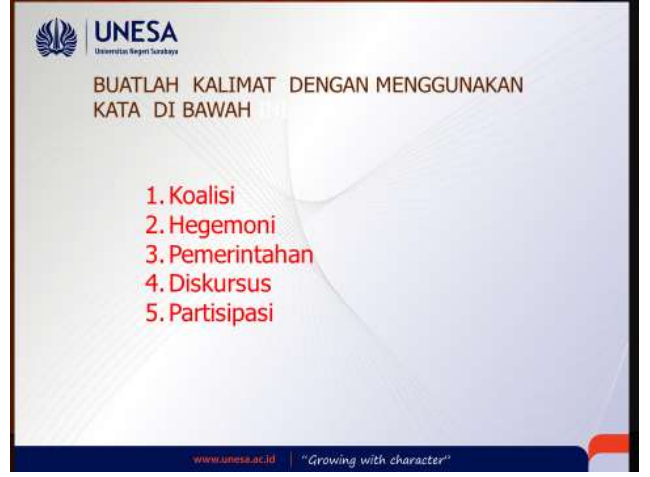

Gambar 5.3 Materi tentang Pengetahuan Berpikir Logis (Sumber: data primer)

Tulisan yang dihasilkan peserta telah berbentuk paragraph, tetapi ide yang ditampilkan sangat sederhana dan cenderung terkait dengan hal-hal yang bersifat konseptual. Peserta seperti tampak tidak memiliki ide untuk ditulis.

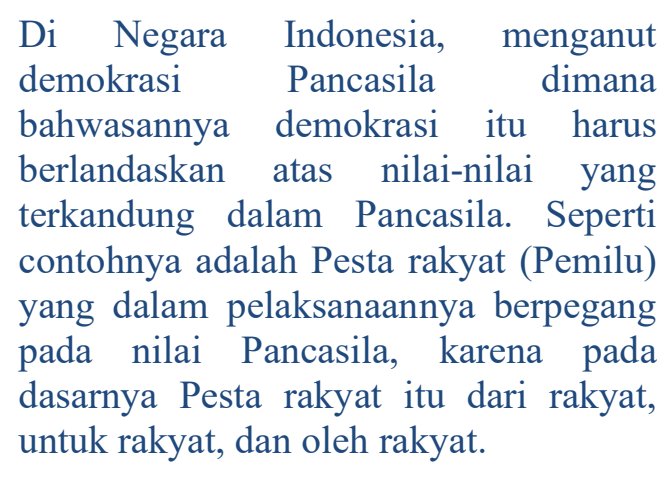

Gambar 5.4 Materi tentang Pengetahuan Berpikir Logis (Sumber: data primer)

1. Sistem Pemerintahan di Indonesia. Bentuk negara kesatuan dan bentuk pemerintahan adalah Republik.

2. Sebagai partisipasi di masyarakat dalam memperingati Hari Proklamasi di RT diadakan berbagai lomba.

3. Pengertian koalisi adalah sebuah atau sekelompok gabungan yang mempunyai kepentingan. Contoh koalisi Prabowo.

Gambar 5.5 Materi tentang Pengetahuan Berpikir Logis (Sumber: data primer)

Jika dicermati, kalimat-kalimat yang dibangun pun belum tertata dalam tata $\mathrm{Ba}$ hasa Indonesia yang baik dan benar. Ide yang dikemukakan pun masih belum tuntas. Pada kalimat nomor tiga misalnya, kepentingan apa yang dimaksud dengan itu?

Tahap selanjutnya, peserta didik diminta menghubungkan beberapa konsep yang diharapkan dapat membantu mereka dalam memikirkan ide untuk ditulis.

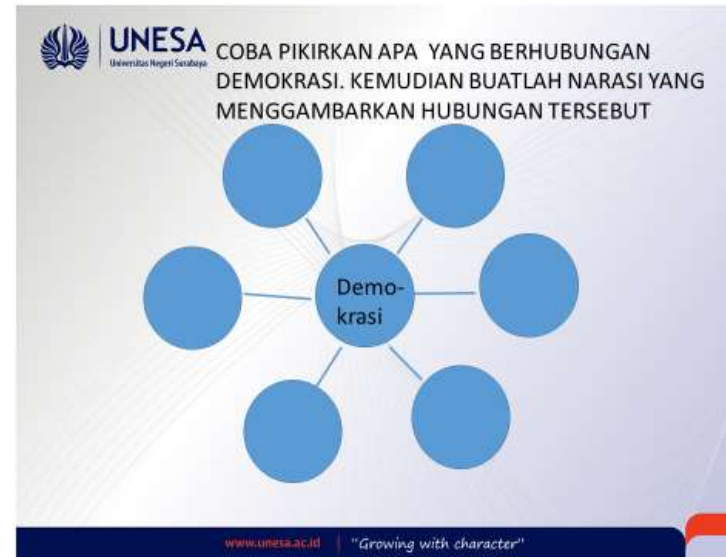

Gambar 5.6 Materi tentang Pengetahuan Berpikir Logis (Sumber: data primer)

Seorang peserta melengkapi bagan tersebut, kemudian menuliskan konsep-konsep yang ditulis tersebut.

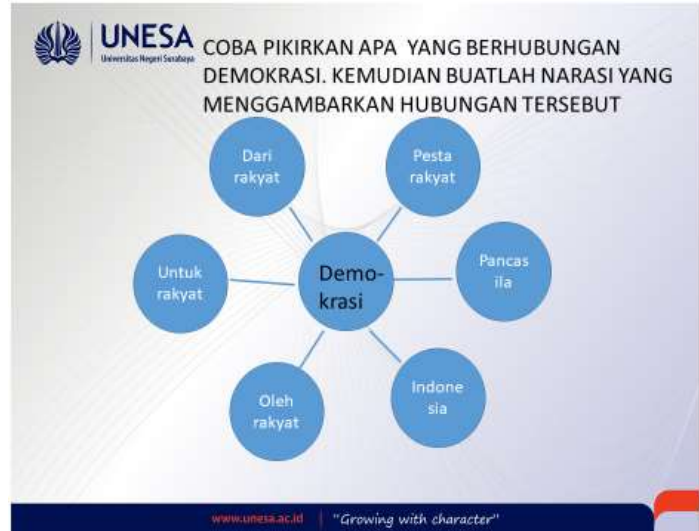

Gambar 5.7 Materi tentang Pengetahuan Berpikir Logis (Sumber: data primer)

Jika dicermati, peserta telah berubaya menulis sebuah paragraph. Namun masih banyak ditemukan persoalan terkait itu. Kekuarangan yang dapat ditemukan dalam tulisan tersebut antara lain penggunaan kata "dimana"yang tidak tepat dan ditulis secara salah. Seperti digunakan bersama-sama dengan contohnya.Kedua kata ini memiliki penertian yang sama. Ide yang ditulis dengan tidak tuntas. "Pesta rakyat (Pemilu) yang dalam pelaksanaannya berpegang pada nilai Pancasila," yang mana? Karena stiwa di 
berbagai daerah di Indonesia, memang ada pesta rakyat lain yang dimaksudkan untuk merayakan sebuah peristiwa.

Berdasarkan data latihan yang diperoleh tersebut, hampir dapat dipastikan bahwa modalitas guru dalam menulis memang masih rendah, baik dari sisi kebahasaan maupun materi, serta logika. Karena itu untuk keluar dari persoalan mereka terkait dengan penulisan ilmiah, diperlukan latihan dan pendampingan yang lebih banyak.

\section{Respon Guru terhadap Pelaksanaan Kegiatan}

Kegiatan ini nyaris berjalan tanpa hambatan. Kegiatan berlangsung lancer sampai selesai. Semua guru terlibat aktif dalam kegiatan yang dilakukan dalam bentuk mengerjakan latihan atau bertanya selama proses kegiatan berlangsung. Kegiatan diikuti oleh semua peserta pada hari pertama dan kedua. Setelah kegiatan selesai, tim meminta respon peserta terkait dengan penyelenggaraan kegiatan PKM yang dilaksanakan. Hasil dari respon tersebut disajikan pada tabel 4.

Tabel 4 Respon Guru terhadap pelaksanaan Kegiatan

\begin{tabular}{|c|c|r|}
\hline Kelas Interval & Katagori & $\mathrm{f}$ \\
\hline skor $8-15$ & KURANG BAIK & 0 \\
\hline skor $16-23$ & CUKUP BAIK & 0 \\
\hline skor $24-31$ & BAIK & 3 \\
\hline skor $32-40$ & SANGAT BAIK & 22 \\
\hline JUMLAH & & 25 \\
\hline
\end{tabular}

Sumber: data primer

Secara umum dapat dikemukakan bahwa kegiatan ini berjalan dengan sangat baik, terdapat 22 peserta (88\%) yang menyatakan itu dan hanya 3 peserta (12\%) yang menyatakan baik. Perbedaan jumlah peserta yang menyatakan itu menjadi alasan yang cukup untuk menyatakan bahwa kegiatan PKM ini berjalan dengan sangat baik. Meskipun demikian, penting untuk diperhatikan bahwa hal yang dinilai seorang peserta masih perlu ditingkatkan adalah pemberian waktu latihan lebih lanjut.

Ketepatan waktu dalam pelaksanaan kegiatan merupakan persoalan yang dinilai paling rendah, hal ini karena terkait ada kegiatan lain di kabupaten yang harus diikuti oleh sekolah-sekolah di Kabupaten Magetan.

Selain itu, menunggu kedatangan guru-guru peserta juga merupakan salah satu penyebab ketidaktepatan waktu kegiatan.

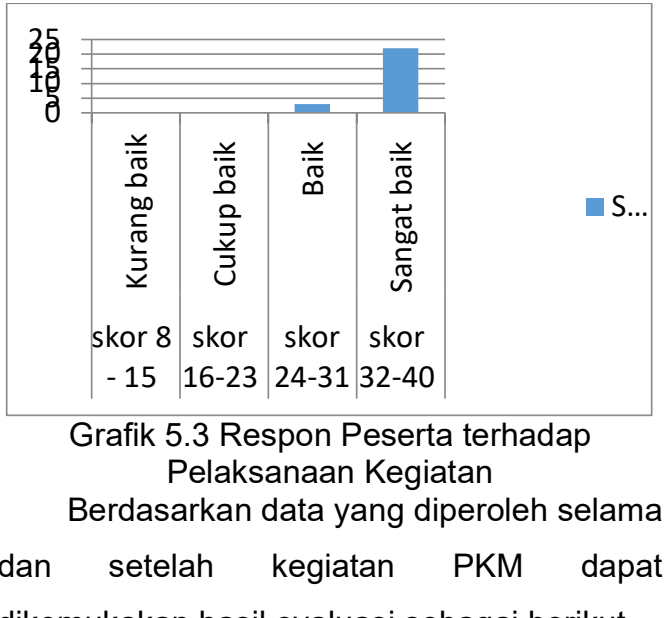

dikemukakan hasil evaluasi sebagai berikut.

Tabel 5.5 Rekap Hasil Evaluasi

\begin{tabular}{|c|c|c|}
\hline NO & Indikator & Hasil Evaluasi \\
\hline 1 & Aspek Proses & \\
\hline & $\begin{array}{l}\text { Keaktifan peserta dalam mengikuti } \\
\text { kegiatan }\end{array}$ & $\begin{array}{l}\text { Semua peserta hadir pada hari pertama } \\
\text { dan kedua dan mengikuti kegiatan sampai } \\
\text { selesai. }\end{array}$ \\
\hline & Faktor penghambat dan pelancar & Nyaris tidak ada, kecuali sebagian kecil \\
\hline
\end{tabular}




\begin{tabular}{|r|l|l|}
\hline NO & \multicolumn{1}{|c|}{ Indikator } & \multicolumn{1}{c|}{ Hasil Evaluasi } \\
\hline & kegiatan & $\begin{array}{l}\text { peserta yang dating terlambat dan kegiatan } \\
\text { kabupaten yang menuntut penyesuaian } \\
\text { kegiatan. }\end{array}$ \\
\hline 2 & Aspek Hasil & \multicolumn{1}{|c|}{} \\
\hline $\begin{array}{l}\text { Respon guru terhadap kegiatan } \\
\text { PKM yang dilaksanakan }\end{array}$ & $\begin{array}{l}88 \% \text { peserta menyatakan pelaksanaan } \\
\text { kegiatan dalam katagori sangat baik }\end{array}$ \\
\hline $\begin{array}{l}\text { Pengetahuan guru-guru tentang } \\
\text { materi logika berpikir dalam } \\
\text { penulisan ilmiah }\end{array}$ & $\begin{array}{l}96 \% \text { guru memiliki pengetahuan tentang } \\
\text { berpikir logis dalam penulisan ilmiah }\end{array}$ \\
\hline $\begin{array}{l}\text { Produk draft tulisan ilmiah yang } \\
\text { dihasilkan oleh guru. }\end{array}$ & $\begin{array}{l}\text { Draf tulisan yang dihasilkan guru belum } \\
\text { final namun logika dalam menulis telah } \\
\text { meningkat. }\end{array}$ \\
\hline
\end{tabular}

\section{SIMPULAN DAN SARAN \\ - Simpulan}

Kegiatan pengabdian ini telah berhasil dalam meningkatkan pengetahuan peserta tentang berpikir logis. Sebanyak $96 \%$ peserta telah menguasai materi pengetahuan berpikir logis dalam penulisan ilmiah pada katagori sangat baik.

Kegiatan pengabdian ini telah berhasil dalam meningkatkan pengetahuan peserta tentang pengembangan kemampuan berpikir logis yang diperlukan dalam penulisan ilmiah. Namun untuk dapat menulis ilmiah yang dapat dipubllikasikan perlu, diperlukan latihan dan pendampingan yang lebih intensif.

\section{- Saran}

Kemampuan guru dalam menulis ilmiah sebagai lanjutan dari kegiatan pengembangan berpikir logis ini masih perlu dikembangkan lebih lanjut. Kegiatan PKM ini dapat dilanjutkan dengan menguatkan kemampuan guru dalam menulis ilmiah.

\section{DAFTAR PUSTAKA}

De Bono, Edward, 2013. Teach Your Child How to Think. New York: Penguin Group.

Depdiknas Dirjen Dikdasmen Direktorat Tenaga Kependidikan. 2001. Pedoman Penyusunan Karya Tulis IImiah di Bidang Pendidikan dan Angka Kredit Pengembangan Profesi Guru. Jakarta.

Ennis, Robert H. 1993. Critical Thinking Assessment. Theory into Practice, 32, 179-186.

https://doi.org/10.1080/00405849309543 594.
Ennis, Robert H. 1996. "Critical Thinking Dispositions: Their Nature and Assessability" Informal Logic Vol. 18, Nos. 2 \& 3 (1996): 165-182.

Epstein, R.L. (2006). Critical thinking. Toronto: Thomson Wadsworth.

Fisher, A. 2009. Berpikir Kritis. Sebuah Pengantar. Jakarta: Erlangga.

https://lensamagetan.com/2018/11/05/calopkt-berkeliaran-ini-kata-ketua-pgrimagetan/https://radarsurabaya.jawapos.co $\mathrm{m} / \mathrm{read} / 2018 / 06 / 23 / 82581 /$ kemampuanguru-menulis-masih-minim. Didownload tanggal 21 Maret 2021.

https://radarsurabaya.jawapos.com/read/2018 /06/23/82581/kemampuan-guru-menulismasih-minim. Didownload tanggal 21 Maret 2021.

Hurley, Patrick J. dan Lori Watson, 2018. A Concise Introduction to Logic. Edisi ke13. Boston: Cengage Learning

Minto, Barbara, 2003. The Minto Pyramid Principle: Logic in Writing, Thinking and Problem Solving. USA: Minto International.

Moore, B.N. and Parker, R. 2009. Critical Thinking. USA: McGraw-Hill.

Noorjannah, Lilies, "Pengembangan Profesionalisme Guru melalui Penulisan Karya Tulis IImiah bagi Guru Profesional di SMA Negeri 1 Kauman Kabupaten Tulungagung." Jurnal Humanity, ISSN 0216-8995.

https://media.neliti.com/media/publications /11406-ID-pengembanganprofesionalisme-guru-melalui-penulisan- 
Oksiana Jatiningsih, dkk., Penguatan Kemampuan Berpikir ...

karya-tulis-ilmiah-bagi-guru.pdf.

Didownload tanggal 25 Maret 2021. pp. 97-114.

Norris, S. P. \& Ennis, R. H. (1989). Evaluating Critical Thinking. Pacific Grove, CA: Midwest Publications.

Norris, Stephen P. dan Robert H. Ennis, 1991. "Evaluating Critical Thinking." Journal of Educational Measurement. Vol. 28, No. 4 (Winter, 1991), pp. 355-357

Paul, R., Fisher. A. dan Nosich, G. 1993. "Foundation for Critical Thinking."

Suryasumantri, 1996. Filsafat IImu. Sebuah Pengantar. Jakarta: Pustaka Sinar Harapan.
Workshop on Critical Thinking Strategies. CA: Sonoma State University.

Sumardjoko, Bambang. 2017. "Pemetaan Kemampuan Guru dalam Penulisan Karya IImiah" dalam THE $5^{\text {th }}$ URECOL PROCEEDING 191. 18 February 2017. ISBN 978-979-3812-42-7. Yogyakarta: UAD. pp.191-198.

Sumaryono, E., 1999.Dasar-Dasar Logika. Yogyakarta: Kanisius. 